\title{
Association Between Sociodemographic, Obstetric and Pathologic Factors with Late Fetal Death: A Case-Control Study in a Hospital in Peru
}

\author{
Andrés Modesto Martínez-López ${ }^{1 *}$, Javier Roger Raúl Vargas-Herrera² and Elsy Haydee Mini-Díaz ${ }^{3}$ \\ ${ }^{1}$ Obstetrician, Graduate of the Master's Degree in Public Health, Universidad Nacional Mayor de San Marcos, Peru \\ ${ }^{2}$ Surgeon Physician, Master in Epidemiology, Universidad Nacional Mayor de San Marcos, Peru \\ ${ }^{3}$ Surgeon Physician, Master in Public Health and Health Management, Universidad Nacional Mayor de San Marcos, Peru
}

Submission: March 09, 2021; Published: March 16, 2021

*Corresponding author: Andrés Modesto Martínez-Lopez, Obstetrician, Graduate of the Master's Degree in Public Health, Universidad Nacional Mayor de San Marcos, Peru

\begin{abstract}
Introduction: In Peru, little is known about the risk factors associated with late fetal death to implement prevention strategies.

Objectives: To determine the sociodemographic, obstetric and pathological factors associated with late fetal death.

Methods: Retrospective study of cases and controls between July 2014 and June 2016. The cases were pregnant women who had intrauterine fetal death and controls were pregnant women who had a newborn alive.
\end{abstract}

Results: 60 cases and 120 controls were included. Primary education level $(\mathrm{OR}=4.3 ; \mathrm{CI}=1.0-18.0)$, working occupation $(\mathrm{OR}=3.8 ; \mathrm{CI}=1.3$ $11.0)$, no $C P N s(O R=21,0 ; C I=2.6-170.1)$, preeclamsia $(O R=4.1 ; C I=1.3-12.7)$, preterm birth $(\mathrm{OR}=10.1 ; \mathrm{CI}=4.7-21,7)$ and intrauterine growth retardation (RCIU) $(\mathrm{OR}=7.0$; $\mathrm{CI}=2.4-20.5)$ were associated with fetal mortality.

Conclusion: There are associated sociodemographic, obstetric and pathological risk factors during pregnancy to have late fetal death.

Keywords: Fetal death; Associated factors; Prenatal controls

\section{Introduction}

In Peru, a late fetal death rate of 8.6 per thousand pregnancies [1] was determined during 2013. In the United States, 7 late fetal deaths occur per 1,000 live newborns. In Spain the annual late fetal mortality rate between 2000 and 2011 was 3-4 per thousand of the total births [2]. Around 2, 6 million fetal deaths occur each year (fetuses $>28$ weeks or $>1000 \mathrm{~g}$ of weight) $[3,4]$. Due to the different definitions of stillbirth used in eachcountry, approximately $98 \%$ of deaths occur in developing countries, whose mortality rates range from 9 to 34 fetal deaths per 1,000 live births, compared to 3,1 fetal deaths per 1,000 live births in developed countries [3-5].

The study topic of this project is late fetal death, statistical data provided by the Hospital Epidemiology Office were used, the database was purified, to establish cases of fetal deaths greater than 28 weeks. Clinical records of cases with perinatal card were selected to identify continuous and periodic timely prenatal control, both by specialized medical staff and obstetrics.

The World Health Organization recommends the use of the term late fetal mortality. The international statistical classification of diseases and health-related problems (ICD-10) defines late fetal mortality as the rate of fetuses born dead over 28 weeks, greater than 1000gr in weight, or with a skull-rump length greater than $35 \mathrm{~cm}$ [6]. words: fetal death, associated factors, prenatal controls.

In recent decades, the study of late fetal mortality has become important, to the extent that its close dependence on biological, demographic and social factors has been identified, which make 
it a sensitive indicator not only during this final event, but the repercussions and morbidity that precede it [7]. We consider it necessary and relevant to carry out this investigation, because in Callao, it is not yet clear that factors predispose to late fetal death. The objective of this study was to determine the sociodemographic and obstetric factors associated with late fetal death at the Daniel Alcides Carrión National Hospital (HNDAC), Callao, Peru.

\section{Methods}

A retrospective, observational and analytical study of cases and controls was carried out in pregnant women that were attended at HNDAC in Callao between July 2014 and June 2016. Pregnant women over 28 weeks of age who had intrauterine stillbirth were included as cases. As controls, pregnant women of 28 weeks or more whose birth result was a live newborn were selected. Cases and controls were matched by due to the mother's due date of care and age in a ratio of 1:2. To determine the sample size, the case and control formula was used by comparing proportions. The prevalence for cases was $23 \%$ ( $\mathrm{p} 1$ ), for the determination of prevalence in trolls the prevalence of $6 \%$ was applied with a confidence of $95 \%$ (alpha Z) and a poder of $80 \%$ (Z beta).

An expertly validated data collection sheet was used to collect sociodemographic, obstetric, associated pathologies and perinatal information on maternal-perinatal medical records. Sociodemographic factors included age, marital status, educational level, economic level, occupation, tobacco and alcohol use. Obstetric factors included prenatal control (CPN), parity, prior stillbirth, nutritional status, prepartum bleeding, placenta premature detachment [DPP], placenta previa, cord circular and maternal trauma. The mother's pathological findings included gestational diabetes, preeclampsia, chronic hypertension, and urinary treatment infection [ITU]). Perinatal information included, gestational age of product, fetal sex and intrauterine growth delay [RCIU].

Abivariate analysis with the Chi squared test with a value of $p<0.05$ and Odds ratio (OR) with a confidence interval (CI) of $95 \%$ were used to determine the association between sociodemographic, obstetric and pathological factors with late fetal death. Scans were performed on SPSS software version 22.0 for Windows. The study was approved by the ethics committee of Daniel Alcides Carrión National Hospital. The researchers maintained absolute confidentiality of the information obtained from maternal-perinatal medical records.

\section{Results}

During the study period 9,961 pregnant people were treated at HNDAC. Of these pregnant men, 110 had an intrauterine fetal death (11 per thousand live births [110/9961). The calculation of sample size was determined by the prevalence of cases and controls, with a confidence of $95 \%$ and a power of $80 \%$ applying the formula for analytical studies obtaining 60 cases and 120 controls in a ratio of 1:2.

\section{Sociodemographic factors}

The average age was similar between cases and controls $(27.5$ years vs. 26.9 years). Primary educational level (OR: 4.3; 95\% CI: 1.0 to $18.0 ; p<0,030)$ and dependent worker occupation (OR: 3.8; $95 \%$ CI: 1.3 to $11.0 ; p<0,010$ ) were associated with late fetal death. The other sociodemographic factors were similar in cases and controls (Table 1).

Table 1: Factores sociodemográficos asociados con la muerte fetal tardía.

\begin{tabular}{|c|c|c|c|c|c|}
\hline & & No. (\%) & & & \\
\hline Factor & Total, No. (\%) & $\operatorname{Casos}(n=60)$ & Controles $(n=120)$ & OR (IC 95\%) & p valor* \\
\hline \multicolumn{6}{|c|}{ Edad Materna (Años) } \\
\hline $15-19$ & $29(16,1)$ & $9(15)$ & $20(16,7)$ & $0,9(0,4-2,1)$ & 0,774 \\
\hline $20-24$ & $41(22,8)$ & $15(25)$ & $26(21,7)$ & $1,2(0,6-2,5)$ & 0,615 \\
\hline $25-29$ & $47(26,1)$ & $13(21,7)$ & $34(28,3)$ & $0,7(0,3-1,5)$ & 0,337 \\
\hline $30-34$ & $37(20,6)$ & $13(21,7)$ & $24(20)$ & $1,1(0,5-2,4)$ & 0,794 \\
\hline $35-39$ & $16(8,9)$ & $6(10)$ & $10(8,3)$ & $1,2(0,4-3,5)$ & 0,711 \\
\hline $40-44$ & $9(5)$ & $3(6)$ & $6(5)$ & $1(0,2-4,1)$ & 1,000 \\
\hline $45-49$ & $1(0,6)$ & $1(1,7)$ & $0(0,0)$ & $0,9(0,9-1,0)$ & 0,156 \\
\hline \multicolumn{6}{|l|}{ Estado Civil } \\
\hline Soltero & $28(15,6)$ & $12(20)$ & $16(13,3)$ & $1,6(0,7-3,7)$ & 0,245 \\
\hline Conviviente & $129(71,7)$ & $39(65)$ & $90(75)$ & $0,6(0,3-1,2)$ & 0,160 \\
\hline Casado & $23(12,8)$ & $9(15)$ & $14(11,7)$ & $1,3(0,5-3,3)$ & 0,528 \\
\hline \multicolumn{6}{|c|}{ Nivel Educativo } \\
\hline Primaria & $9(5)$ & $6(10)$ & $3(2,5)$ & $4,3(1,0-18,0)^{* *}$ & 0,030 \\
\hline
\end{tabular}




\section{Journal of Gynecology and Women's Health}

\begin{tabular}{|c|c|c|c|c|c|}
\hline Secundaria & $142(78,9)$ & $46(76,7)$ & $96(80)$ & $0,8(0,4-1,7)$ & 0,605 \\
\hline Superior no universitaria & $22(12,2)$ & $5(8,3)$ & $17(14,2)$ & $0,6(0,2-1,6)$ & 0,260 \\
\hline Superior universitaria & $7(3,9)$ & $3(5)$ & $4(3,3)$ & $1,5(0,3-7,1)$ & 0,586 \\
\hline Ocupación & & & & \\
\hline Ama de casa & $134(74,4)$ & $42(70)$ & $92(76,7)$ & $0,7(0,4-1,4)$ & 0,334 \\
\hline Estudiante & $11(6,1)$ & $3(5)$ & $8(6,7)$ & $0,7(0,2-2,9)$ & 0,660 \\
\hline Trabajadora dependiente & $16(8,9)$ & $10(16,7)$ & $6(5)$ & $3,8(1,3-11,0)^{* *}$ & 0,010 \\
\hline Comerciante & $19(10,6)$ & $5(8,3)$ & $14(11,7)$ & $0,7(0,2-2,0)$ & 0,493 \\
\hline
\end{tabular}

Abbreviations: OR, odds ratio; IC, intervalo de confianza.

${ }^{*}$ Chi cuadrado; ${ }^{* *} p<0,05$

† No se encontraron hallazgos de antecedente de consumo de tabaco, consumo de alcohol y antecedentes de muerte fetal tardía entre los casos y controles

\section{Obstetric factors}

Pregnant women who had less than five CPNs (OR: 2.2; IC95\%: 1.1 to $4.8 ; p<0,033$ ) or had no CPN (OR: $21.0 ; 95 \%$ CI: 2.6 to 170.1 ; $p<0,0001$ ) were at increased risk of late fetal death (Table 2).

Table 2: Factores obstétricos asociados con la muerte fetal tardía.

\section{Pathological findsors}

Preeclamsia (OR: 4.1; IC95\%: 1.3 to $12.7 ; p<0,011$ ), preterm gestation (OR:10,1; 95\% CI: 4.7 to $21.7 ; p<0,0001$ ) and the RCIU (OR: 7.0 ; $95 \%$ CI: 2.4 to $20.5 ; p<0,0001$ ) were associated with late fetal death (Table 3).

\begin{tabular}{|c|c|c|c|c|c|}
\hline & & No. (\%) & & & \\
\hline Factor & Total, No. (\%) & $\operatorname{Casos}(n=60)$ & Controles $(n=120)$ & OR (IC 95\%) & p valor* \\
\hline \multicolumn{6}{|l|}{ Control Prenatal } \\
\hline Sin CPN & $11(6,1)$ & $9(15)$ & $2(1,7)$ & $21(2,6-170,1)^{* *}$ & 0,000 \\
\hline De 1 a 4 CPN & $35(19,4)$ & $17(28,3)$ & $18(15)$ & $2,2(1,1-4,8)^{*}$ & 0,033 \\
\hline De 5 a más CPN & $134(74,4)$ & $34(56,7)$ & $100(83,3)$ & $0,2(0,1-0,5)$ & 0,000 \\
\hline \multicolumn{6}{|l|}{ Paridad } \\
\hline Primera gestación & $51(28,3)$ & $19(31,7)$ & $32(26,7)$ & $1,3(0,6-2,5)$ & 0,483 \\
\hline Dos o más gestaciones & $129(71,7)$ & $41(68,3)$ & $88(73,3)$ & $0,8(0,4-1,5)$ & 0,483 \\
\hline \multicolumn{6}{|l|}{ Estado Nutricional } \\
\hline Normal & $82(47,9)$ & $24(40,6)$ & $58(51,7)$ & $0,6(0,3-1,2)$ & 0,167 \\
\hline Bajo peso & $23(13,4)$ & $8(13,5)$ & $15(13,3)$ & $1,0(0,4-2,6)$ & 0,958 \\
\hline Sobrepeso & $29(16,9)$ & $10(16,9)$ & $19(16,9)$ & $1,0(0,4-2,3)$ & 0,998 \\
\hline Obesidad & $37(21,6)$ & $15(25,4)$ & $22(19,6)$ & $1,8(0,8-3,7)$ & 0,132 \\
\hline
\end{tabular}

Abbreviations: CPN, control prenatal; OR, odds ratio; IC, intervalo de confianza.

${ }^{*}$ Chi cuadrado; ${ }^{* *} p<0,05$

Table 3: Hallazgos patológicos asociados a la muerte fetal tardía†.

\begin{tabular}{|c|c|c|c|c|c|}
\hline & & No. (\%) & & \\
\hline Factores & Total, No. (\%) & Casos (n = 60) & Controles (n = 120) & OR (IC 95\%) & p valor* \\
\hline ITU & $38(21,1)$ & $12(20)$ & $26(21,7)$ & $0,9(0,4-1,9)$ & 0,796 \\
\hline Preeclampsia & $14(7,8)$ & $9(15)$ & $5(4,2)$ & $4,1(1,3-12,7)^{* *}$ & 0,011 \\
\hline Hemorragias & $6(3,3)$ & $6(10)$ & $0(0,0)$ & $0,9(0,8-1,0)$ & 0,000 \\
\hline DPP & $6(3,3)$ & $6(10)$ & $0(0,0)$ & $0,9(0,8-1,0)$ & 0,000 \\
\hline Diabetes gestacional & $3(1,7)$ & $3(5,0)$ & $0(0,0)$ & $1,0(0,9-1,0)$ & 0,014 \\
\hline Hipertensión crónica & $1(0,6)$ & $1(1,7)$ & & $1,0(0,9-1,01)$ & 0,156 \\
\hline
\end{tabular}




\section{Journal of Gynecology and Women's Health}

\begin{tabular}{|c|c|c|c|c|c|}
\hline Hallazgos Del Feto & & & & \\
\hline Parto a término & $134(74,4)$ & $27(45)$ & $107(89,2)$ & $0,1(0,05-0,2)$ & 0,000 \\
\hline Parto pretérmino & $46(25,6)$ & $33(55)$ & $13(10,8)$ & $10,1(4,7-21,7)^{* *}$ & 0,000 \\
\hline Sexo fetal masculino & $99(55,0)$ & $36(60)$ & $63(52,5)$ & $1,4(0,7-2,5)$ & 0,340 \\
\hline RCIU & $19(10,6)$ & $14(23,3)$ & $5(4,2)$ & $7,0(2,4-20,5)^{* *}$ & 0,000 \\
\hline
\end{tabular}

†No se encontraron hallazgos de placenta previa, circular de cordón, trauma materno y antecedentes de muerte fetal tardía entre los casos y controles

Abbreviations: OR, odds ratio; IC, intervalo de confianza; DPP, desprendimiento prematuro de placenta; ITU, infección del tracto urinario; RCIU, retardo del crecimiento intrauterino.

${ }^{*}$ Chi cuadrado; ${ }^{* *} \mathrm{p}<0,05$

\section{Discussion}

Perinatal death is a global problem reaching figures of 10 per 1000 live births in North America, however, the records do not follow uniform inclusion criteria, so it is estimated that there are 5.3 fetal deaths per 1000 live births (range 4.2 to 6.8 ) in developed countries, and 25.5 (range 20 to 32 ) in underdeveloped countries [8]. We define risk factors as characteristics associated with the problem without an obvious direct relationship, while the causes are conditions in which a feasible mechanism is known to lead to the problem.

The findings found in this study are related to the low level of education and migration of families from our mountains and forest of the country that settle in human settlements from which cases of fetal death related to the absence of prenatal control and incomplete controls and in other cases associated with pathological factors such as preclamsia and history of RCIU and pretermbirth. Like the findings of Fustamante, et al. [9] and Martínez, et al. [10] those who report that pregnant women who have lower educational levels and work outside the home are at increased risk of late fetal death, in this study we find that pregnant women who have primary education level and be dependent workers during pregnancy were associated with late fetal death. The mother's low educational level is a risk factor for stillbirth The educational level can provide a higher socioeconomic status, thus accessing health care, as well as longer intergenetic periods which are known to reduce the risk of fetal and perinatal mortality [11-15].

In general, our results are consistent with what is reported by international literature. Of the socioeconomic factors, the low school grade, coupled with poor prenatal control, were the factors most found in the literature [12,13]; this was entirely conclusive in our study, which reported that the predominant profile in women with late fetal death attended at Daniel Alcides Carrión National Hospital was the low school grade and being a dependent worker.

In relation to the background that can undermine the optimal development of the product, in this study we find no history of smoking and alcohol consumption for the group of cases and controls. As for obstetric factors, in this study we find that HNDAC pregnant women who have less than 5 CPNs or do not have any CPNs have high chances of having a late fetal dead woman, similar to what was found in the previous literature $[12,13]$. These results are comparable to the findings of Martínez et al. [10] those who found that in adequate CPNs increase the risk of obital 9 times.

Therefore, it is suggested to sensitize women of childbearing potential to the importance of CPNs, mainly from the stage of preparation or preconception and also to pregnant women from the beginning of the first CPN in order to avoid fetal deaths. Diseases such as systemic high blood pressure, diabetes mellitus and obesity are pathological entities considered 21st century epidemics because of their high prevalence at the national level and their devastating multiorgan complications with which they are associated, these, as well as systemic pregnancy pathologies such as gestational diabetes and hypertensive pregnancy states (mild preeclampsia and severe preeclampsia) are related to multiple maternal and fetal adverse events such as intrauterine death (11,14-17)

Like literature, $[10,17]$ in this study we found that preeclapmsia, RCIU and preterm childbirth were associated with late fetal death. This could probably be happening due to the absence of CPNs, which would be leading to the detection of these factors late.

In relation to the weeks of gestation it was found that the greatest frequency was in preterm with $55 \%$ (odss 10.1), higher than reported by Martínez et al. ${ }^{(10)}$ which was 53\% (odss 8.3 ). leading to the detection of these factors late. Intrauterine growth restriction is one of the most relevant risk factors in perinatal morbidity according to literature reports, which have associated it with an increase up to 10 times greater intrauterine stillbirth than a properly grown fetus $[15,18]$. In our study it is associated with an increase up to 7 times greater late fetal death. In our study there are $9(15 \%)$ preeclamsia pathologies for the case group, of which $3(30 \%)$ they studied with RCIU. Also, of the total cases [14] with RCIU pathology, only 7 (50\%) pregnant women had 5 or more prenatal checkups.

In addition to the total cases of preeclamsia, 33\% were subjected to premature placental abruption. From all this we induce the little knowledge that exists around this subject and 
the little research that has been carried out. Optimal assessment of fetal death is a subject of controversy and there is very little data to guide clinicians [16]. The most commonly identifiable cause of late fetal death reported by the epidemiology office of Daniel Alcides Carrión National Hospital is very important, as this study found $24(40 \%)$ cases with fetus and newborn affected by un defied maternal condition, secondly 15 (25\%) cases with anencephaly, hydropsia, hydrocephalus, malformations, 6 (10\%) cases with fetus and newborn affected by hypertensive disorders of the mother, $2(3.3 \%)$ cases with newborn mother syndrome with gestational diabetes and $13(21.7 \%)$ cases with other causes.

The main limitation of our study lies in retrospective design, since when the data from secondary sources (medical records) were obtained, many medical records had to be purged for cases and controls because they were incomplete or not have the perinatal medical history, extending the time period of the study, and finding association between the other socioeconomic, obstetric and pathological factors and late fetal death. However, to address this limitation, a cohort study could be carried out in the future. Another limitation of our study is that it does not include autopsy results, thus making it difficult to know the true causes of fetal death, which, although not objective of this work would have been important because of the number of fetal deaths studied.

In conclusion, this retrospective study found pregnant women who have a lower level of education, work in dependently during pregnancy, have less than five CPNs, preeclapmsia, a preterm birth and/or RCIU, have a high risk of having a late fetal death. Therefore, these risk factors are still monitored and identified in a timely manner to avoid late fetal mortality.

\section{Source of Funding}

This study was self-funded by the authors.

\section{References}

1. National Institute of Statistics and Informatics (2013) National Survey of Demographics and Health 2013.ENDES Lima pp. 206-209.

2. Valladares Z (2013) Intrauterine fetal death: can we act on itsprevention? Chilean Journal of Gynecology and Obstetrics 78(6): 413-418.

3. Lawn JE, Blencowe H, Pattinson R, Cousens S, Kumar R, et al. (2011) Stillbirths: Where? When? Why? How to make the data count? Lancet 377(9775): 1448-1463.
4. Cousens S, Blencowe H, Stanton C, Chou D, Ahmed S, et al. (2011) National, regional, and worldwide estimates of stillbirth rates in 2009 with trends since 1995: a systematic analysis. Lancet 377(9774): 1319-1330.

5. McClure EM, Wright LL, Goldenberg RL, Goudar SS, Parida SN, et al. (2007) The global network: a prospective study of stillbirths in developing countries. Am J Obstet Gynecol 197(3): 247.e1-5.

6. Goldenberg RL, McClure EM, Saleem S, Reddyajbt UM (2010) Infectionrelated stillbirths. Lancet 375(9724): 1482-1490.

7. Idrogo SA (2014) Prenatal Control and its Relationship with Perinatal Morbidity at the Regional Hospital of Loreto during the period january to December 2013. National University of the Peruvian Amazon. Faculty of Medicine, Iquitos - Peru.

8. Molina S, Alfonso D (2010) Fetal death anteparto: is it a preventable condition? Univ Méd Bogotá (Colombia) 51(1): 59-73.

9. Fustamante $N$ (2016) Factors associated with fetal death in two reference hospitals in Lambayeque [Specialty Thesis]. University of San Martín de Porras, Lima, Peru.

10. Martinez C (2014) Epidemiology of fetal death risk factors, hospital of gynecology and obstetrics maternal children's institute of the state of Mexico, 2012. Autonomous University of the State of Mexico, [Specialty thesis] Toluca, Mexico.

11. Silver RM, Varner MW, Reddy U, Goldenberg R, Pinar H, et al. (2007) Work-up of stillbirth: a review of the evidence. Am J Obstet Gynecol 196(5): 433-444.

12. Huertas-Tachino E (2007) Epidemiology of fetal deaths at the Perinatal Maternal Specialized Institute, 2003. Rev Per Ginecol Obstet 53: 199202.

13. Panduro-Barón JG, Vázquez-Granados MD, Pérez-Molina JJ, CastroHernández JF (2006) Prenatal risk factors in late fetal death. Ginecol Obstet Mex 74(11): 573-579.

14. Donald DJ (2007) Intrauterine death associated with diabetes: incidence, physiopathology and prevention. Obstet Gynec Clin N Am 34: 293-307.

15. Druzin Ml, James S (2007) Obstetrics: normal and problem pregnancies. In: Gabbe SC, Niebyl JR, Simpson JL (eds.), In: (5th edn.), Elsevier Churchill Livinsgtong, Philadelphia, pp. 267-300.

16. Kady SM, Gardosi J (2004) Perinatal mortality and fetal growth restriction. Bes Pract Res Clin Obstet Gyneacol 18(3): 397-410.

17. Gabee SG, Graves CR (2003) Management of diabetes mellitus complicating pregnancy. Obstet Gynecol 102(4): 857-868.

18. Schenone MH, Mari G (2011) The MCA Doppler and its role in the evaluation of fetal anemia and fetal growth restriction, Clin Perinatol 38(1): 83-102. 
(C) This work is licensed under Creative DOI: 10.19080/JGWH.2021.21.556058

\section{Your next submission with Juniper Publishers will reach you the below assets}

- Quality Editorial service

- Swift Peer Review

- Reprints availability

- E-prints Service

- Manuscript Podcast for convenient understanding

- Global attainment for your research

- Manuscript accessibility in different formats

( Pdf, E-pub, Full Tsext, Audio)

- Unceasing customer service

Track the below URL for one-step submission

https://juniperpublishers.com/online-submission.php 